\title{
Effects of Therapeutic Ultrasound on Pain, Disability, Walking Performance, Quality of Life, and Depression in Patients with Chronic Low Back Páin: A Randomized, Placebo Controlled Trial
}

\author{
Kronik Bel Ağrılı Hastalarda Ultrason Tedavisinin Ağrı, Disabilite, Yürüme \\ Performansı ve Yaşam Kalitesi Üzerine Etkisi: Randomize Plasebo Kontrollü Çalışma
}

\author{
Dilek Durmuş, Yeşim Akyol, Kıvanç Cengiz, Tülay Terzi, Ferhan Cantürk \\ Ondokuz Mayıs Üniversitesi Tıp Fakültesi, Fiziksel Tıp ve Rehabilitasyon Anabilim Dalı, Samsun, Turkey
}

\begin{abstract}
Objective: The aim of the current study was to evaluate the effects of therapeutic ultrasound on pain, disability, walking performance, quality of life (QOL) and depression in patients with chronic low back pain (CLBP).

Materials and Methods: Forty-two patients with CLBP were randomly allocated into two groups. Patients in group 1 received therapeutic ultrasound, exercise, and hot packs, while patients in group 2 received sham ultrasound, exercise, and hot packs. All treatment programs (ultrasound, sham ultrasound, hot packs, and exercise) were performed 5 days a week for 3 weeks. Patients were evaluated by the following parameters: pain (visual analog scale [VAS]), disability (Modified Oswestry Low Back Pain Disability Questionnaire and Pain Disability Index), functional performance (6-Minute Walk Test [6MWT]), QOL (Short Form 36 [SF-36]), and depression (Beck Depression Inventory [BDI]).

Results: A significant improvement was noted in both groups in pain, disability, walking performance, QOL and depression after treatment. Significantly greater improvement was observed in group 1 compared to group 2 in pain, emotional and physical role functioning, functional performance, and depression.

Conclusion: Therapeutic ultrasound was shown to be effective on pain, some particular parameters of QOL, functional performance, and depression in patients with CLBP.

(Turk J Rheumatol 2010; 25: 82-7)
\end{abstract}

Key words: chronic low back pain, therapeutic ultrasound, pain, walking performance, quality of life

Received: 29.12.2008

Accepted: 30.03.2009

\section{Özet}

Amaç: Bu çalıșmanın amacı, kronik bel ağrısı (KBA) olan hastalarda tedavide kullanılan ultrasonun (US) ağrı, fonksiyon, yașam kalitesi ve depresyona olan etkisini değerlendirmektir.

Yöntem ve Gereçler: KBA'sı olan 42 hasta rastgele iki gruba dağıtıldı. Grup 1 sıcak paket, US ve egzersiz tedavisi aldı, grup 2 kontrol grubu olarak kabul edildi (sıcak paket, plasebo US ve egzersiz tedavisi). Bütün tedaviler (US, plasebo US, sıcak paket ve egzersiz) 3 hafta süreyle haftada 5 gün uygulandı. Hastaların ağrısı visual analog skala (VAS), disabilitesi Düzeltilmis Oswestry Özürlülük Sorgulama formu (DOÖS) ve Ağrı Özürlülük Indeksi (AÖi), fonksiyonu 6 dakika yürüme testi (6DYT), yașam kalitesi kısa form-36 (SF-36) ve depresyon Beck Depresyon Ölçeği (BDÖ) ile değerlendirilmiștir.

Bulgular: Tedavi sonrasında her iki grupta ağrı, disabilite, yürüme performansı, yașam kalitesi ve depresyonda çok anlamlı gelișme tespit edildi. İki grup karșılaștırıldığında VAS ağrı, 6DYT, SF-36'nın fiziksel rol ve emosyonel roldeki kısıtlılık parametrelerini içeren alt grupları ve BDÖ değerlerinde grup 1'de grup 2'ye göre daha anlamlı gelișme bulundu.

Sonuç: Bu çalıșmada tedavide kullanılan US'nin KBA'lı hastalarda ağrıya, yașam kalitesinin bazı parametrelerine, fonksiyonel performansa ve depresyona etkili olduğunu tespit ettik.

(Turk J Rheumatol 2010; 25: 82-7)

Anahtar sözcükler: Kronik bel ağrısı, ultrason, ağrı, yürüme performansı, yașam kalitesi

Alındığı Tarih: 29.12.2008 Kabul Tarihi: 30.03.2009

\section{Introduction}

Chronic low back pain (CLBP) is a significant public health problem due to its high prevalence and associated socioeconomic cost (1). CLBP is defined as the presence of low back pain for $>12$ weeks (2). The prevalence of CLBP ranges from $20 \%-40 \%$ in developed countries and from $30 \%-85 \%$ worldwide. CLBP is more common between 35 and 64 years of age. The prevalence of CLBP was reported to be $34.2 \%$ in Turkey (3). 
Unless treated, CLBP may lead to significant disability in performing activities of daily living (ADL). The relationship between symptoms and the level of disability in performing ADL might be quite complicated. Social and psychological factors are known to be important in the development of CLBP and in the process of becoming a chronic problem. Prolongation of the painful period also has a significant negative impact on the daily functions of the patient (4).

Therapeutic ultrasound (US) is frequently used in the management of musculoskeletal disorders (5). It has been demonstrated that US exerts thermal and mechanical effects which leads to an increase in blood flow and metabolic activity, thus enhancing the regeneration and elasticity of the target tissue (6). The efficacy of US in musculoskeletal disorders is controversial due to the limited number of studies with qualified methodology $(5,7)$.

The aim of this study was to determine the effects of therapeutic US, widely used in clinical practice, on pain, functional capacity, quality of life (QOL), and depression in patients with CLBP.

\section{Materials and Methods}

Forty-two patients (29 females and 13 males) with CLBP lasting for at least 3 months were included in the study. Patient age (years), body mass index (BMl; kg/m²), occupation, and duration of symptoms were recorded. All patients were examined thoroughly by the same physicians; routine laboratory test results as well as radiographs were evaluated. Patients were excluded from the study for the following reasons: evidence for acute radiculopathy; the presence of an inflammatory disease, neoplastic disease, spondylolysis, spondylolisthesis or sacroiliitis; lumbar disc herniation requiring surgical treatment; vertebral fractures; pregnancy. The study was approved by the local Ethics Committee and written informed consent was obtained from all patients.

The consecutive patients were randomly allocated into two groups. This was a single-blind study. Patients were treated 5 days a week for 3 weeks. Group 1 patients received hot packs (15 minutes), US, and exercise, and group 2 patients received hot packs (15 minutes), sham US, and exercise.

\section{Therapeutic ultrasound}

In group 1, continuous US (Sonopuls 434, Enraf Nonius, Al-Delft, The Netherlands) was applied to the lumbar paravertebral region at a $1 \mathrm{MHz}$ frequency at an intensity of $1 \mathrm{~W} \mathrm{~cm} \mathrm{~cm}^{2}$ for 10 minutes using a probe with an effective radiating area of $5 \mathrm{~cm}^{2}$.

Sham US was applied to the same region for the same duration in group 2 patients. The same US device was used. No current was applied but the device and the indicator lights were kept in the "on" position.

\section{Therapeutic exercise}

Both groups performed range of motion, stretching (hamstring, pelvic, and abdominal muscles) and strengthening (cervical, thoracic, and lumbar region muscles) exercises for 15 minutes.

\section{Clinical Assessment}

Pain

The severity of pain was assessed using a visual analog scale (VAS). Patients were asked to place a mark along a $100-\mathrm{mm}$ line that best describes the severity of pain they were currently experiencing. Pain was assessed at rest as well as during activity.

\section{Disability}

The Modified Oswestry Low Back Pain Disability Questionnaire (m-OSW) consists of 10 items; each item is scored from 0-5. Items include pain intensity, personal care, lifting, walking, sitting, standing, sleeping, employment/homemaking, traveling, and social life $(8,9)$. The total score ranges from 0-50. The disability level is increased by an increased total score.

The Pain Disability Index (PDI) consists of 7 items, including family/home responsibilities, social activity, recreation, self-care, occupation, sexual behavior, and lifesupport activity $(9,10)$. Each item is scored from $0-10$, with 0 indicating no disability and 10 indicating worst disability. The total score ranges from $0-70$, with 0 indicating no disability and 70 indicating severe disability.

\section{Functional performance}

The 6-minute walk test (6MWT) was performed by measuring the distance (in meters) the patient could walk in 6 minutes.

\section{Quality of life}

The Short Form-36 (SF-36; the MOS 36-item shortform health survey) is a widely used measure of QOL and consists of 36 items evaluating physical functioning, physical role functioning, emotional role functioning, social role functioning, general health, mental health, bodily pain, and vitality (11). Scores for 8 domains are calculated by summing up the item scores, which are coded in such a way that each domain is scored from $0-100$, with 0 indicating the worst health status and 100 indicating the best health status.

\section{Depression}

The Beck Depression Inventory (BDI) consists of 21 items (12). Each of the 21 items on the BDI consists of four statements. These statements are placed in an order from a neutral state ( 0 points) to the worst state (3 points). The statements composing this scale have been taken from the statements of actual patients being treated for depression. The patients are asked to choose one of the four statements which best describes their feelings. The 
Table 1. Demographic characteristics of the patients

\begin{tabular}{|c|c|c|c|}
\hline & $\begin{array}{c}\text { Group } 1 \\
(F / M=15 / 6)\end{array}$ & $\begin{array}{c}\text { Group } 2 \\
(F / M=14 / 7)\end{array}$ & $\mathbf{p}$ \\
\hline Age, years $($ mean $\pm S D)$ & $42.00 \pm 8.93$ & $41.52 \pm 7.94$ & 0.870 \\
\hline $\mathrm{BMI}, \mathrm{kg} / \mathrm{m}^{2}(\operatorname{mean} \pm \mathrm{SD})$ & $28.28 \pm 3.81$ & $27.57 \pm 4.11$ & 0.820 \\
\hline Duration of symptoms, years (mean \pm SD) & $7.14 \pm 7.00$ & $6.71 \pm 5.71$ & 0.838 \\
\hline \multicolumn{4}{|l|}{ Occupation, n (\%) } \\
\hline Housewife & $7(33.4)$ & $7(33.4)$ & 0.606 \\
\hline Retired & $2(9.5)$ & $1(4.8)$ & \\
\hline Government officer & $10(47.6)$ & $9(42.8)$ & \\
\hline Worker & $2(9.5)$ & $4(19.0)$ & \\
\hline
\end{tabular}

Table 2. Clinical parameters in the study groups before and after treatment

\begin{tabular}{lcccccc}
\hline & Before treatment & $\begin{array}{c}\text { Group 1 } \\
\text { After treatment }\end{array}$ & $\mathbf{p}$ & Before treatment & $\begin{array}{c}\text { Group 2 } \\
\text { After treatment }\end{array}$ \\
\hline m-OSW, \% (median [range]) & $38(26-76)$ & $12(1-32)$ & 0.001 & $44(22-50)$ & $17(6-23)$ & 0.001 \\
VAS at rest (median [range]) & $6(3-10)$ & $2(1-5)$ & 0.001 & $6(3-9)$ & $4(1-9)$ & 0.01 \\
VAS during activity (median [range]) & $5(0-5)$ & $2(0-5)$ & 0.001 & $5(0-5)$ & $4(3-5)$ & 0.001 \\
PDI (median [range]) & $30(0-58)$ & $21(0-66)$ & 0.01 & $30(4-57)$ & $20(1-52)$ & 0.01 \\
6MWT, m (mean \pm SD) & $517.57 \pm 89.59$ & $584.90 \pm 101.32$ & 0.001 & $495.42 \pm 57.65$ & $525.95 \pm 54.27$ & 0.001 \\
\hline m-OSW: Modified Oswestry Low Back Pain Disability Questionnaire; VAS: Visual & Analog Scale; PDI: Pain Disability Index; 6MWT: 6-Minute Walk Test; \\
SD: Standard Deviation & & & &
\end{tabular}

Table 3. Change in clinical parameters after treatment in the study groups

\begin{tabular}{lccc}
\hline & Group 1 & Group 2 & p \\
\hline $\begin{array}{l}\text { m-OSW, \% } \\
\text { (median [range]) }\end{array}$ & $8(2-36)$ & $6(0-22)$ & 0.347 \\
$\begin{array}{l}\text { VAS at rest } \\
\text { (median [range]) }\end{array}$ & $4(1-7)$ & $2(0-6)$ & 0.001 \\
$\begin{array}{l}\text { VAS during activity } \\
\text { (median [range]) }\end{array}$ & $2(0-4)$ & $1(0-4)$ & 0.410 \\
$\begin{array}{l}\text { PDI } \\
\text { (median [range]) }\end{array}$ & $8(0-22)$ & $6(0-37)$ & 0.338 \\
$\begin{array}{l}\text { 6MWT, m } \\
\text { (mean } \pm \text { SD) }\end{array}$ & $57.80 \pm 32.91$ & $30.52 \pm 31.63$ & 0.004 \\
$\begin{array}{l}\text { m-OSW: Modified Oswestry Low Back Pain Disability } \\
\text { VAS: Visual Analog Scale; PDI: Pain Disability Index; 6MWT: 6-Minute Walk } \\
\text { Test; SD: Standard Deviation }\end{array}$ & & & \\
\hline
\end{tabular}

highest score is 63 and scores of $0-13$ are rated as no depression, 14-24 as moderate depression, and over 25 as severe depression.

The above-mentioned parameters were measured in all patients before and after treatment.

\section{Statistical Analysis}

Statistical analysis was conducted using SPSS for Windows (Version 13.0; SPSS Inc., Chicago, IL, USA). Normality of data distribution was assessed using the Kolmogorov-Smirnov test. Data were presented as mean \pm standard deviation or median (range). Inter-group comparisons of normally-distributed data were performed using Student's t-test while the Mann Whitney-U test was used for inter-group comparisons of non-normally-distributed data. While a paired-t test was used for intra-group comparisons of normally-distributed data, we performed intra-group comparisons of non-normally distributed data by using the Wilcoxon signed ranks test. The two groups were compared in terms of occupation by a chi-square test. A $p$ value $<0.05$ was considered statistically significant.

\section{Results}

The mean age was $42.00 \pm 8.93$ years and the mean duration of disease was $7.14 \pm 7.00$ years in group 1. The mean age was $41.52 \pm 7.94$ years and the mean duration of disease was $6.71 \pm 5.71$ years in group 2 ( $p>0.05)$. The demographic characteristics of the study population are presented in Table 1. There was no significant difference between the groups in terms of demographic characteristics $(p>0.05)$. There was no significant difference between the groups in terms of pain, disability, functional performance, QOL, and depression before treatment.

Pain, disability, and the functional performance in the study groups before and after treatment are presented in Table 2. A significant improvement was noted in all of these clinical parameters in both groups after treatment. When the groups were compared in terms of a change in clinical parameters, a significantly greater improvement was noted in functional performance and pain at rest in group 1 compared to group 2 (Table 3 ). 
Table 4. Depression and quality of life scores in the study groups before and after treatment (All results are presented as the mean \pm standard deviation unless stated otherwise)

\begin{tabular}{lcccccc}
\hline & Before treatment & $\begin{array}{c}\text { Group 1 } \\
\text { After treatment }\end{array}$ & $\mathbf{p}$ & Before treatment & $\begin{array}{c}\text { Group 2 } \\
\text { After treatment }\end{array}$ \\
\hline Depression* & $9(0-37)$ & $8(0-30)$ & 0.001 & $12(4-32)$ & $10(1-30)$ & 0.01 \\
SF-36 domains & & & & & & \\
Physical functioning & $58.33 \pm 16.83$ & $67.14 \pm 15.61$ & 0.001 & $52.62 \pm 18.48$ & $60.48 \pm 19.35$ & 0.001 \\
Mental health & $60.14 \pm 15.15$ & $67.62 \pm 14.62$ & 0.01 & $56.67 \pm 20.85$ & $62.38 \pm 18.75$ & 0.01 \\
General health perceptions & $53.24 \pm 18.80$ & $58.33 \pm 16.62$ & 0.01 & $50.19 \pm 22.89$ & $55.24 \pm 22.61$ & 0.01 \\
Social role functioning & $60.67 \pm 15.22$ & $67.14 \pm 13.99$ & 0.01 & $53.10 \pm 24.52$ & $59.67 \pm 19.37$ & 0.01 \\
Physical role functioning & $57.14 \pm 22.99$ & $72.48 \pm 18.87$ & 0.001 & $52.81 \pm 28.17$ & $56.10 \pm 27.45$ & 0.01 \\
Emotional role functioning & $63.14 \pm 25.69$ & $73.24 \pm 23.16$ & 0.01 & $58.38 \pm 29.62$ & $63.43 \pm 27.85$ & 0.01 \\
Vitality & $53.33 \pm 16.68$ & $65.24 \pm 13.73$ & 0.001 & $50.95 \pm 17.14$ & $58.10 \pm 16.76$ & 0.01 \\
Bodily pain* & $55(11-70)$ & $65(23-88)$ & 0.001 & $44(0-77)$ & $50(11-80)$ & 0.001 \\
\hline *Presented as the median (range) & & & & & & \\
SF-36: Short Form-36 & & & & & &
\end{tabular}

Table 5. Change in depression and quality of life scores after treatment in the study groups (All results are presented as the median [range])

\begin{tabular}{lccc}
\hline & Group 1 & Group 2 & $\mathbf{p}$ \\
\hline $\begin{array}{l}\text { Depression } \\
\text { SF-36 domains }\end{array}$ & $2(0-16)$ & $1(0-11)$ & 0.049 \\
Physical functioning & $0.5(0-0.30)$ & $0.05(0-0.50)$ & 0.497 \\
Mental health & $0.08(0-0.24)$ & $0.04(0-0.32)$ & 0.187 \\
General health perceptions & $0.05(0-0.20)$ & $0(0-0.21)$ & 0.808 \\
Social role functioning & $0.05(0-0.23)$ & $0.05(0-0.34)$ & 0.979 \\
Physical role functioning & $0.10(0-1)$ & $0(0-0.25)$ & 0.003 \\
Emotional role functioning & $0.05(0-0.67)$ & $0(0-0.33)$ & 0.041 \\
Vitality & $0.10(0-0.35)$ & $0.10(0-0.20)$ & 0.790 \\
Bodily pain & $0.14(0-0.77)$ & $0.05(0-0.45)$ & 0.132 \\
\hline SF-36: Short Form-36 & & & \\
\hline
\end{tabular}

Depression and QOL in the study groups before and after treatment are presented in Table 4. A significant improvement was noted in the BDI scores and in the eight SF-36 domain scores in both groups after treatment. When the groups were compared in terms of a change in these parameters, a significantly greater improvement was noted in the depression, and physical and emotional role functioning in group 1 compared to group 2 (Table 5).

\section{Discussion}

We aimed to evaluate the effects of therapeutic US on clinical parameters, such as pain, walking performance, QOL, and depression in patients with CLBP. We noted a significant improvement in pain, disability, walking performance, depression, and QOL in both groups after treatment. Improvement in pain, walking performance, depression, and the physical and emotional role functioning was significantly greater in the US group compared to the sham US group.
Several studies have investigated the effectiveness of therapeutic US, a widely used physiotherapeutic agent, in the management of musculoskeletal diseases either alone or in combination or in comparison with other physiotherapeutic agents (13-15). Studies evaluating different treatment sites, treatment modalities (pulsed-continuous), and frequencies have also been conducted (16-19). As there are relatively limited number of studies investigating the effectiveness of therapeutic US in patients with CLBP, we prefer to evaluate this patient population (20). In a comparative study of Koldas et al. (21) patients with CLBP received continuous US at a $1 \mathrm{MHz}$ frequency and an intensity of $1.5 \mathrm{~W} \mathrm{~cm} \mathrm{~cm}^{2}$ for 10 minutes in each session; the sessions were practiced 3 times a week for 6 weeks. In a study of Unlu et al. (22) patients with lumbar disc herniation received continuous US at a $1 \mathrm{MHz}$ frequency at an intensity of $1.5 \mathrm{~W} \mathrm{~cm}^{2}$ for 8 minutes in each session; the sessions were practiced 5 times a week for 3 weeks. Ozcan et al. (23) performed a total of 15 US treatment sessions (at an intensity of $1.5 \mathrm{~W} \mathrm{~cm} \mathrm{~cm}^{2}$ for $10 \mathrm{~min}-$ utes) in 3 weeks. In agreement with the literature, we performed a total of 15 continuous US treatment sessions (at a $1 \mathrm{MHz}$ frequency at an intensity of $1 \mathrm{~W} \mathrm{~cm} \mathrm{~cm}^{2}$ for 10 minutes) in 3 weeks.

In addition to the mechanical and biological effects, the rise in temperature as a result of absorption and transformation of US energy in tissues is thought to play a significant role in the effectiveness of therapeutic US (24). It has been suggested that pain threshold can be elevated by the increase in tissue temperature (25).

Besides classical knowledge, controversial reports also exist concerning the effectiveness of US in patients with CLBP. It was stated in the Philadelphia Panel that there was no scientific evidence demonstrating the effectiveness of US in CLBP $(20,26)$. In contrast, the "Québec Task Force" (QTF) reported that therapeutic US in combination with hot packs might be an alternative treatment meth- 
od to reduce muscle spasm and symptomatic pain (27). Grubisic et al. (28) evaluated the effectiveness of therapeutic US in 31 patients with CLBP. While they reported a reduction in pain intensity in the US group compared to the placebo group, they did not note a significant difference regarding the efficacy of the treatment (physiatrist and patient global assessment). Similarly, we noted that US treatment was effective on pain.

Chronic pain has been found to be associated with disability, depression, and decreased QOL $(27,29,30)$. It has been found that emotional disorders and depression are more frequent in patients with CLBP compared to patients with acute LBP (31). The effects of pharmacologic treatment, psychotherapy, exercise, and combined physical therapy on pain, disability, and depression in patients with CLBP have been evaluated in several studies $(32,33)$. However, to our knowledge, no previous studies have evaluated the effects of therapeutic US on disability, depression, and QOL (21). Our results suggest that therapeutic US provides improvement in depression and QOL through its pain-reducing effects.

There were some limitations to our study. It might have been better to design a treatment group in which US was performed as a single therapeutic agent. It is possible that the more significant improvement noted in the US group could be due to the direct effects of US, but also might be associated with the combined effect produced by US, hot packs, and exercise in this group. Functional improvement and pain reduction may most often be sufficient for patients to return to ADL and work. Long-term follow-up of patients is needed to draw a definite conclusion in this respect. We have not yet performed an assessment of long-term follow-up in our patients.

In conclusion, we believe that addition of therapeutic US to superficial heat and exercise increases the effectiveness of treatment in patients with CLBP. Moreover, we believe that our results may provide significant contribution to guidelines for the management of CLBP and further long-term studies on this subject, including larger patient samples, will also be beneficial.

\section{Conflict of Interest}

No conflict of interest is declared by authors.

\section{References}

1. Van Der Roer N, Van Tulder MW, Barendse JM, van Mechelen W, Franken WK, Ooms AC, et al. Cost-effectiveness of an intensive group training protocol compared to physiotherapy guideline care for sub-acute and chronic low back pain: design of a randomised controlled trial with an economic evaluation. BMC Musculoskelet Disord 2004; 5: 45.

2. Quittan M. Management of back pain. Disabil Rehabil 2002; 24: 423-34.

3. Oksuz E. Prevalence, risk factors, and preference-based health states of low back pain in a Turkish population. Spine 2006; 31: 968-72.
4. Uden $A$, Aström $M$, Bergenudd $H$. Pain drawings in chronic back pain. Spine 1988; 13: 389-92.

5. Van der Windt DA, van der Heijden GJ, van den Berg SG, ter Riet G, de winter AF, Bouter LM. Ultrasound therapy for musculoskeletal disorders: a systematic review. Pain 1999; 81: 257-71.

6. Maxwell L. Therapeutic ultrasound: its effects on the cellular and molecular mechanisms of inflammation and repair, Physiotherapy 1992; 78: 421-6.

7. Rakel B, Barr JO. Physical modalities in chronic pain management. Nurs Clin North Am 2003 Sep; 38: 477-94.

8. Yakut $E$, Düger T,Oksüz $C$, Yörükan $S$, Ureten $K$, Turan $D$, et al. Validation of the Turkish version of the Oswestry Disability Index for patients with low back pain. Spine 2004; 29: 581-5

9. Grönblad M, Hupli M, Wennerstrand P, Jarvinen E, Lukinmaa A, Kouri JP, et al. Intercorrelation and test-retest reliability of the pain disability index (PDI) and the oswestry disability questionnaire (ODQ) and their correlation with pain intensity in low back pain patients. Clin J Pain1993; 9: 189-95.

10. Ketenci A. Bel ağrılarında fonksiyonel değerlendirme. In: Özcan E, Ketenci A, eds. Bel Ağrısı. İstanbul: Nobel Kitabevi 2002; 3: 73-83.

11. Kvien TK, Kaasa S, Smedstad LM. Performance of the Norwegian SF-36 Health Survey in patients with rheumatoid arthritis. II. A comparison of the SF-36 with disease-specific measures. J Clin Epidemiol 1998; 51: 1077-86.

12. Beck AT, Ward $\mathrm{CH}$, Mendelson M, Mock J, Erbaugh J. An inventory for measuring depression. Arch Gen Psychiatry 1961; 4: 561-71.

13. Falconer J, Hayes KW, Chang RW. Effect of ultrasound on mobility in osteoarthritis of the knee: a randomized clinical trial. Arthritis Care Res 1992; 5: 29-35.

14. Robertson VJ, Baker KG. A review of therapeutic ultrasound: effectiveness studies. Phys Ther 2001; 81: 1339-50.

15. Eyigör S, Karapolat H, İbisoğlu U, Durmaz B. Diz osteoartritinde transkutanöz elektriksel sinir stimulasyonu veya tedavi edici ultrason kullanımı egzersizin etkinliğini artırır mı?: Randomize-kontrollü çalıșma. Ağrı 2008; 20: 32-40.

16. Ebenbichler GR, Resch KL, Nicolakis P, Wiesinger GF, UhI F, Ghanem $\mathrm{AH}$, et al. Ultrasound treatment for treating the carpal tunnel syndrome: randomised "sham" controlled trial. BMJ 1998; 316: 731-5.

17. Lundeberg $T$, Abrahamsson $P$, Haker E. A comparative study of continuous ultrasound, placebo ultrasound, and rest in epicondylalgia. Scand J Rehabil Med 1988; 20: 99-101.

18. Huang $M H$, Lin $Y S$, Lee $C L$, Yang RC. Use of ultrasound to increase effectiveness of isokinetic exercise for knee osteoarthritis. Arch Phys Med Rehabil 2005; 86: 1545-51.

19. Ozgönenel L, Aytekin E, Durmusoglu G. Double blind trial of clinical effects of therapeutic ultrasound in knee osteoarthritis. Ultrasound Med Biol 2009; 35: 44-9. Epub 2008 Oct 2.

20. Philadelphia Panel Evidence-Based Clinical Practice Guidelines on Selected Rehabilitation Interventions for Low Back Pain. Phys Ther 2001; 81: 1641-74.

21. Koldaș Doğan S, Sonel Tur B, Kurtaiș Y, Atay MB. Comparison of three different approaches in the treatment of chronic low back pain. Clin Rheumatol 2008; 27: 873-81.

22. Unlu Z, Tasci S, Tarhan S, Pabuscu Y, Islak S. Comparison of 3 physical therapy modalities for acute pain in lumbar disc herniation measured by clinical evaluation and magnetic resonance imaging. J Manipulative Physiol Ther 2008; 31: 191-8.

23. Özcan ME, Yurtsızoğlu Ö, Balki S, Altay Z, Eğri M. Bel ağrısı olan hastalarda hot-pack, TENS, ultrasound ve egzersizin 
HAMD skorlarına etkisi. Anadolu Psikiyatri Dergisi 2000; 1 26-31.

24. Tuncer T. Elektroterapi. Beyazova M, Kutsal YG (ed): Fiziksel Tıp ve Rehabilitasyon. Güneș Kitabevi, Ankara, 2000, S: 771-89.

25. Lehmann JF, Bunner GD, Stow RW. Pain threshold measurements after therapeutic application of ultrasound, microwaves and infrared. Arch Phys Med Rehabil 1958; 39: 560-5.

26. Harris GR, Susman JL. Managing musculoskeletal complaints with rehabilitation therapy: summary of the Philadelphia Panel evidence-based clinical practice guidelines on musculoskeletal rehabilitation interventions. J Fam Pract 2002; 51: 1042-6.

27. Québec Task Force on Spinal Disorders. Scientific approach to the assessment and management of activity-related spinal disorders: a monograph for clinicians. Spine 1987; 12: 51-9.

28. Grubisic F, Grazio S, Jajic Z, Nemcic T. Therapeutic ultrasound in chronic low back pain treatment. Reumatizam 2006; 53: 18-21.
29. Bair MJ, Wu J, Damush TM, Sutherland JM, Kroenke K. Association of depression and anxiety alone and in combination with chronic musculoskeletal pain in primary care patients. Psychosom Med 2008; 70:890-7.

30. Meyer T, Cooper J, Raspe H. Disabling low back pain and depressive symptoms in the community-dwelling elderly: a prospective study. Spine 2007; 32: 2380-6.

31. Gatchel RJ, Bernstein D, Stowell AW, Pransky G. Psychosocial differences between high-risk acute vs. chronic low back pain patients Pain Pract 2008; 8: 91-7.

32. Ko JK. Comparing the effects of drug therapy, and exercise on pain, disability, and depression in patients with chronic low back pain. Taehan Kanho Hakhoe Chi 2007; 37: 645-54.

33. Hoffman BM, Papas RK, Chatkoff DK, Kerns RD. Metaanalysis of psychological interventions for chronic low back pain. Health Psychol 2007; 26: 1-9. 